\title{
Sagebrush, Common and Uncommon, Palatable and Unpalatable
}

\author{
By E. Durant McArthur
}

I read with interest Jim Brunner's recent view point arti$\mathrm{cle}^{1}$ where he briefly traced the recognition of palatable forms of sagebrush. Jim's keen sense of differences in sagebrush taxa were first published more than 3 decades ago. ${ }^{2}$ Jim's comments stimulated some thoughts of my own about the recognition, distribution, and palatability of sagebrush taxa. I'm sharing some of those thoughts here.

Sagebrush is an icon of the American West. ${ }^{3}$ However, it is a symbol that stirs a range of emotions among rangeland managers. ${ }^{4-7}$ An appreciation for the values of sagebrush ecosystems has been a long time coming and, unfortunately, is juxtaposed with a fragmentation of that resource over much of its historic range. ${ }^{4,5}$ That is not to say that there are areas that may not need management, including reduction of sagebrush density, but more often, in my opinion, the weightier need is for restoration and enhancement.

Sagebrush ecosystems are varied and rich in indigenous and multitudinous forms of life. Some forms are obligate to their sagebrush habitat, eg, greater sage-grouse, Gunnison sage-grouse, pygmy rabbits, sage thrasher, and sage sparrow. ${ }^{4,5}$

Brunner ${ }^{1}$ pointed out that sagebrush is diverse in form and in its acceptance as forage for animals (palatability). Some taxa are common; others are not. Big sagebrush is the central and most important species to the group that forms its own portion of the large genus Artemisia - the subgenus Tridentatae (Table 1). This group is composed of wholly western North American endemics, although Artemisia in general, through representation of its other subgenera, occurs widely around the world. I believe there are 6 kinds (subspecies) of big sagebrush. Three of these are common throughout the distributional range of the subgenus and species, which is nearly the same. The geographic range of the subgenus is only slightly larger than that of big sagebrush itself, to the northeast by silver sagebrush (Artemisia cana) and to the southeast by Bigelow sagebrush (A. bigelovii). ${ }^{8}$ The common subspecies are basin, mountain, and Wyoming big sagebrushes, respectively, the subspecies tridentata, vaseyana, and wyomingensis. These subspecies each have distinctive morphological differences and habitat preferences but can be distributed in close proximity. ${ }^{9}$ The distribution of basin big sagebrush in particular is highly fragmented because the deep, well-drained soils that it prefers are prime agricultural and urban lands. Mountain big sagebrush is sometimes divided into 2 varieties based on the number of flowers per head. The common mountain big sagebrush east of the Cascade-Sierra axis is sometimes termed variety pauciflora to contrast it with the plants with larger flower heads that occur at higher elevations and latitudes (variety vaseyana of ssp. vaseyana). Both are quite similar, and I am comfortable in calling both "mountain big sagebrush." The recognition of Wyoming big sagebrush has expanded widely during my career. It was not described until $1965 .{ }^{10} \mathrm{I}$ well remember my introduction to bona fide Wyoming big sagebrush. It was at the field trip of the 1973 Wyoming Shrub Ecology Workshop held in Pinedale. Alan Beetle, who with his student Alvin Young had described the subspecies, led the field trip to the type location. Before that time, my experience with what I thought was Wyoming big sagebrush had been with what has subsequently been formally described as Lahontan low sagebrush (A. arbuscula ssp. longicaulis). ${ }^{11} \mathrm{My}$ mentor Perry Plummer had many accessions of sagebrush growing at the Snow Field Station in Ephraim, Utah, among which were accessions of Lahontan low sagebrush, which had been collected as seedling transplants from northwestern Nevada as "widelobe" with the sobriquet "an ecotype of Wyoming big sagebrush" from Alan Beetle through Jim Brunner. After I had learned what typical Wyoming big sagebrush was really like at the Wyoming Shrub Ecology Workshop, I saw that it was widely distributed, but previously unrecognized, in many locations. Others have recognized this wide distribution as well; published studies recognize it in 11 states. ${ }^{12,13}$ It is always tetraploid (has 4 sets of chromosomes), whereas basin and mountain big sagebrush are usu- 
Table 1. Sagebrush (subgenus Tridentatae) taxa (species and subspecies) with their general distributions and site adaptation

\begin{tabular}{|c|c|c|}
\hline Species & Subspecies & Distribution and site adaptation \\
\hline \multirow{3}{*}{$\begin{array}{l}\text { Low sagebrush (Artemesia } \\
\text { arbuscula) }\end{array}$} & $\begin{array}{l}\text { Low sagebrush } \\
\text { (arbuscula) }\end{array}$ & $\begin{array}{l}\text { W WY to S central WA and N CA on dry sterile, } \\
\text { rocky, shallow, alkaline, clay soils }\end{array}$ \\
\hline & $\begin{array}{l}\text { Cleftleaf sagebrush } \\
\text { (thermopola) }\end{array}$ & $\begin{array}{l}\text { W WY, N UT, and E ID on spring-flooded, summer- } \\
\text { dry soils }\end{array}$ \\
\hline & $\begin{array}{l}\text { Lahontan low sagebrush } \\
\text { (Iongicaulis) }\end{array}$ & $\begin{array}{l}\text { NW NV extending into adjacent CA, OR, and ID on } \\
\text { soils of low water-holding capacity and shallow } \\
\text { depth usually around and above the old shoreline } \\
\text { of Lake Lahontan }\end{array}$ \\
\hline Coaltown sagebrush ( $A$. argillosa) & & Jackson County, CO on alkaline spoil material \\
\hline Bigelow sagebrush ( $A$. bigelovii) & & $\begin{array}{l}\text { Four-corners area extending to NE UT, SE CA, and } \\
\text { W TX on rocky, sandy soils }\end{array}$ \\
\hline \multirow{3}{*}{ Silver sagebrush ( $A$. cana) } & $\begin{array}{l}\text { Bolander silver sagebrush } \\
\text { (bolanderi) }\end{array}$ & E OR, W NV, and N CA in alkaline basins \\
\hline & $\begin{array}{l}\text { Plains silver sagebrush } \\
\text { (cana) }\end{array}$ & $\begin{array}{l}\text { Generally E of Continental Divide, Alberta, and } \\
\text { Manitoba to CO on loamy to sandy soils of river } \\
\text { and stream bottoms }\end{array}$ \\
\hline & $\begin{array}{l}\text { Mountain silver sagebrush } \\
\text { (viscidula) }\end{array}$ & $\begin{array}{l}\text { Generally W of Continental Divide, MT, and OR to } \\
\mathrm{AZ} \text { and NM in mountain areas along streams and } \\
\text { in areas of heavy snowpack }\end{array}$ \\
\hline Alkali sagebrush ( $A$. longiloba) & & $\begin{array}{l}\text { SW MT, NW CO, W WY, N UT, S ID, N NV, and E } \\
\text { OR on heavy soils derived from alkaline shales or } \\
\text { on lighter, limey soils }\end{array}$ \\
\hline \multirow[t]{2}{*}{ Black sagebrush (A. nova) } & $\begin{array}{l}\text { Black sagebrush } \\
\text { (nova) }\end{array}$ & $\begin{array}{l}\text { SE OR and S central MT to S CA and NW NM on } \\
\text { dry, shallow, stony soils with some affinity for cal- } \\
\text { careous conditions }\end{array}$ \\
\hline & 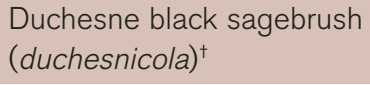 & $\begin{array}{l}\text { NE UT on reddish clay soils of Duchesne River } \\
\text { Formation }\end{array}$ \\
\hline Pygmy sagebrush (A. pygmaea) & & $\begin{array}{l}\text { Central NV and NE UT to N AZ on calcareous } \\
\text { desert soils }\end{array}$ \\
\hline Stiff sagebrush ( $A$. rigida) & & E OR, W central ID, and E WA on rocky scablands \\
\hline Rothrock sagebrush (A. rothrockii) & & $\begin{array}{l}\text { E CA and W NV on deep soils along forest and } \\
\text { meadow margins in Sierra Nevada and outlying } \\
\text { mountain ranges }\end{array}$ \\
\hline \multirow{6}{*}{ Big sagebrush (A. tridentata) } & $\begin{array}{l}\text { Parish big sagebrush } \\
\text { (parishii) }\end{array}$ & $\begin{array}{l}\text { Los Angeles basin area on deep soils in chaparral } \\
\text { and saltbush habitats }\end{array}$ \\
\hline & $\begin{array}{l}\text { Snowbank big sagebrush } \\
\text { (spiciformis) }\end{array}$ & $\begin{array}{l}\text { WY, ID, CO, and UT in high mountains associated } \\
\text { with A. cana ssp. viscidula but in slightly drier areas }\end{array}$ \\
\hline & $\begin{array}{l}\text { Basin big sagebrush } \\
\text { (tridentata) }\end{array}$ & $\begin{array}{l}\mathrm{BC} \text { and } \mathrm{MT} \text { to NM and Baja CA in dry, deep, well- } \\
\text { drained soils on foothills and mountains }\end{array}$ \\
\hline & $\begin{array}{l}\text { Mountain big sagebrush } \\
\text { (vaseyana) }\end{array}$ & $\begin{array}{l}\mathrm{BC} \text { and } \mathrm{MT} \text { to } \mathrm{S} \text { CA and N NM in deep, well- } \\
\text { drained soils on foothills and mountains }\end{array}$ \\
\hline & $\begin{array}{l}\text { Wyoming big sagebrush } \\
\text { (wyomingensis) }\end{array}$ & $\begin{array}{l}\text { ND and WA to AZ and NM on shallower well- } \\
\text { drained soils often underlain by a caliche or silica } \\
\text { layer in valleys and on foothills }\end{array}$ \\
\hline & $\begin{array}{l}\text { Xeric big sagebrush } \\
\text { (xericensis) }\end{array}$ & W central ID on basaltic and granitic soils \\
\hline
\end{tabular}


Table 1. Continued

\begin{tabular}{|c|c|c|}
\hline Species & Subspecies & Distribution and site adaptation \\
\hline Threetip sagebrush ( $A$. tripartita) & $\begin{array}{l}\text { Wyoming threetip sagebrush } \\
\text { (rupicola) }\end{array}$ & W and S WY on rocky knolls \\
\hline & $\begin{array}{l}\text { Tall threetip sagebrush } \\
\text { (tripartita) }\end{array}$ & $\begin{array}{l}\text { E WA and W MT to N NV and N UT on moderate- } \\
\text { to-deep well-drained soils }\end{array}$ \\
\hline
\end{tabular}

ally diploid. ${ }^{12}$ Subsequent work in collaboration with Alma Winward led us to formally describe the wide-lobe taxon as Artemisia arbuscula ssp. longicaulis, ${ }^{11}$ which is likely a stabilized hybrid between typical Wyoming big sagebrush and typical low sagebrush. It, $A$. arbuscula ssp. longicaulis or Lahontan low sagebrush, combines morphological, chemical, and cytological features of the 2 putative parents (the flowers of low sagebrush, the vegetative characteristics of Wyoming big sagebrush, and a combined hexaploid genome or chromosome complement). ${ }^{11}$ Lahontan low sagebrush is a palatable taxon. It is often hedged. It has a relatively limited distribution-northwestern Nevada spilling into adjacent California and Oregon. ${ }^{11}$

The 3 other subspecies of big sagebrush that I recognize are of limited distribution. These are spicate or snowbank big sagebrush, ssp. spiciformis; xeric big sagebrush, ssp. xericensis; and Parish big sagebrush, ssp. parishii. Spicate big sagebrush is a high-elevation taxon of the Intermountain area, of probable hybrid ancestry (mountain big sagebrush $\times$ mountain silver sagebrush) that was formerly confused with Rothrock sagebrush. ${ }^{14}$ Rothrock sagebrush (A. rothrockii) is also a highelevation taxon but is limited to the Sierra Nevada and its outlier mountains and is a high polyploid, with hexaploid and octoploid populations, whereas spicate big sagebrush is diploid and tetraploid. ${ }^{12}$ Xeric big sagebrush is limited in its distribution to west central Idaho; it is a tetraploid taxon derived from putative diploid ancestors, basin ( $A$. tridentata ssp. tridentata) and mountain (A. tridentata ssp. vaseyana $)^{12,15}$ big sagebrush. In other places, basin big sagebrush and mountain big sagebrush have formed hybrid swarms without stabilizing into new polyploid taxa as they apparently did in the case of xeric big sagebrush. ${ }^{16}$ Parish big sagebrush is a narrow endemic that occurs only in the Los Angles basin area of southern California. I had been inclined not to recognize it as a distinct taxon because it is similar to basin big sagebrush. However, I recently examined several natural populations. Its populations have distinctive, bimodal phenotypes with upright and droopy inflorescences and soft, pliable vegetative branches as opposed to the stiffer ones of the basin big sagebrush. In addition, these large, robust plants are tetraploid, whereas the large-basin big sagebrush are diploid. ${ }^{12,17,18}$ The suggestion by Beetle ${ }^{19}$ and Brunner ${ }^{1}$ that
Parish big sagebrush is widespread beyond the Los Angeles basin is, I believe, erroneous. Table 1 lists the general distributions and adaptation of sagebrush taxa.

Individual taxa have become established over geological time as populations filled niches made available through climatic, edaphic, and other environmental variables. These taxa were able to differentiate, I believe, through the processes of isolation and selection with new combinations made possible through hybridization and polyploidy, both of which are important in the Tridentatae. ${ }^{12,16,20}$ Several extant Tridentatae taxa are thought to be of hybrid origin. ${ }^{11,16,20}$ In many places, different taxa occur sympatrically or very close to one another. Hybridization can occur in these areas, although strong selection and ploidy (chromosome number) differences usually preclude speciation. ${ }^{16}$ Winward ${ }^{21}$ has suggested a rather widespread set of populations that he calls informally $A$. tridentata hybrid B (Bonneville big sagebrush), which occupy habitats between mountain and Wyoming big sagebrush and which might, in fact, be a distinct taxon. I and some colleagues ${ }^{12,16,22}$ have argued that these populations might best be viewed as Wyoming big sagebrush that have been introgressed by mountain big sagebrush. All of these populations that have been examined cytologically share the tetraploid condition of Wyoming big sagebrush. ${ }^{12,18}$

As landscape-dominant plants, sagebrushes are important as the host organism and as habitat for many associated species, including species of special concern such as sage grouse, pygmy rabbit, sage thrasher, sage sparrow, Brewer's sparrow, and raptor species. ${ }^{4,5,23}$ The relative palatability of sagebrush species to domestic livestock and wild ungulates generates much of the contrasting judgment by rangeland managers of its value on landscapes. Whereas it is not eaten much by cattle; mule deer, elk, domestic sheep, and antelope consume large quantities of sagebrush. ${ }^{424-28}$ Individual populations, subspecies, and species have been shown to be preferred by different consuming animal species under both natural and controlled conditions. For example, studies have shown that:

- Mule deer prefer mountain big sagebrush and low sagebrush to basin and Wyoming big sagebrush and black sagebrush. ${ }^{25,27,28}$ 
- Greater sage-grouse prefer mountain big sagebrush to basin and Wyoming big sagebrush. ${ }^{29}$

- Domestic sheep preferred Wyoming big sagebrush to mountain and basin big sagebrush in one study ${ }^{26}$ but preferred low sagebrush and black sagebrush to other taxa in another study. ${ }^{28}$

- Lahontan low sagebrush is a preferred taxon by browsing animals. ${ }^{1,2,30}$

- Black sagebrush (A. nova) is palatable in many circumstances to domestic sheep, antelope, and mule deer although often less palatable than big sagebrush. ${ }^{27,28,31-33}$

Author is Project Leader and Research Geneticist at the US Department of Agriculture, Forest Service, Rocky Mountain Research Station, Shrub Sciences Laboratory, 735 North 500 East, Provo, UT 84606-1856; dmcarthur@fs.fed.us. He extends appreciation to A. Clyde Blauer, Stanley G. Kitchen, and Sterwart C. Sanderson for manuscript review.

\section{References}

1. BRUNNER, J. 2005. The semantics of sagebrush. Rangelands 27(1):41.

2. Brunner, J. R. 1972. Observations on Artemisia in Nevada. Journal of Range Management 25:205-208.

3. Trimble, S. 1989. The sagebrush ocean. Reno, NV: University of Nevada Press. 248 p.

4. WeLCH, B. L. 2005. Big sagebrush: a sea fragmented into lakes, ponds, and puddles. Fort Collins, CO: UDSA Forest Service, Rocky Mountain Research Station. General Report RMRSGTR-144. 210 p.

5. Knick, S. T., D. S. Dobkin, J. T. Rotenberry, M. A. Schroeder, W. M. Vander Haegen, and C. Van Riper III. 2003. Teetering on the edge or too late: conservation and research issues for avifauna of sagebrush habitats. The Condor 105:611-634.

6. Whitson, T. D., L. C. Burrill, S. A. Dewey, D. W. Cudney, B. E. Nelson, R. D. Lee, and R. Parker. 1999. Silver sagebrush Artemisia cana Pursh., Big sagebrush Artemisia tridentata Nutt. In: T. D. Whitson [ed.]. Weeds of the west. Newark, CA: Western Society of Weed Science. p. 62-63,68-69.

7. Welch, B. L. 1997. Comment: big sagebrush pro versus con. Journal of Range Management 50:322-323.

8. Mahalovich, M. F., AND E. D. McArthur. 2004. Sagebrush (Artemisia spp.) seed and plant transfer guidelines. Native Plants 5:141-147.

9. McArthur, E. D., ANd R. Stevens. 2004. Composite shrubs. In: S. B. Monsen, R. Stevens, and N. L. Shaw [compilers]. Restoring western ranges and wildlands. Fort Collins, CO: USDA Forest Service, Rocky Mountain Research Station. General Technical Report RMRS-GTR-136-vol-2. p. 493-437.

10. Beetle, A. A., And A. Young. 1965. A third subspecies in the Artemisia tridentata complex. Rhodora 67:405-406.
11. Winward, A. H., AND E. D. McArthur. 1995. Lahontan sagebrush (Artemisia arbuscula ssp. longicaulis): a new taxon. Great Basin Naturalist 55:151-157.

12. McArthur, E. D., And S. C. Sanderson. 1999. Cytogeography and chromosome evolution of subgenus Tridentatae of Artemisia. American Journal of Botany 86:1754-1775.

13. Shultz, L. M. 1986. Taxonomic and geographic limits of Artemisia subgenus Tridentatae (Beetle) McArthur (Asteraceae: Anthemideae). In: E. D. McArthur and B. L. Welch [compilers]. Proceedings—symposium on the biology of Artemisia and Chrysothamnus. Ogden, UT: USDA Forest Service, Intermountain Research Station. General Technical Report INT-200. p. 20-28.

14. McArThur, E. D., AND S. Goodrich. 1986. Artemisia tridentata ssp. spiciformis: distribution and taxonomic placement. In: E. D. McArthur and B. L. Welch [compilers]. Proceedingssymposium on the biology of Artemisia and Chrysothamnus. Ogden, UT: USDA Forest Service, Intermountain Research Station. General Technical Report INT-200. p. 55-57.

15. Rosentreter, R., AND R. G. Kelsey. 1991. Xeric big sagebrush, a new subspecies in the Artemisia tridentata complex. Journal of Range Management 44:330-335.

16. McArthur, E. D., AND S. C. SANDERSon. 1999. Ecotones; introduction, scale, and big sagebrush example. In: E. D. McArthur, W. K. Ostler, and C. L. Wambolt [compilers]. Proceedings: shrubland ecotones. Ogden, UT: USDA Forest Service, Rocky Mountain Research Station. Proceedings RMRS-P-11. p. 3-8

17. Ward, G. H. 1953. Artemisia, section Seriphidium in North America: a cytotaxonomic study. Contributions from the Dudley Herbarium 4:155-205.

18. McArthur, E. D., AND S. C. SANDerson. Unpublished data, on file at the USDA Forest Service, Rocky Mountain Research Station, Shrub Sciences Laboratory, Provo, UT.

19. BeEtLe, A. A. 1960. A study of sagebrush, section Tridentatae of Artemisia. Laramie, WY: Wyoming Agricultural Experiment Station. Bulletin No. 368.83 p.

20. McArthur, E. D., B. L. Welch, and S.C. Sanderson. 1988. Natural and artificial hybridization between big sagebrush (Artemisia tridentata) subspecies. Journal of Heredity 79:268-276.

21. Winward, A. H. 2004. Sagebrush of Colorado, taxonomy, distribution, ecology and management. Denver, CO: Colorado Division of Wildlife. $41 \mathrm{p}$.

22. Goodrich, S., E. D. McArthur, and A. H. Winward. 1999. Sagebrush ecotones and average annual precipitation. In: E. D. McArthur, W. K. Ostler, and C. L. Wambolt [compilers]. Proceedings: shrubland ecotones. Ogden, UT: USDA Forest Service, Rocky Mountain Research Station. Proceedings RMRS-P-11. p. 88-94.

23. Paige, C., And S. A. Ritter. 1999. Birds in a sagebrush sea, managing sagebrush habitats for bird communities. Boise, ID: Partners in Flight Western Working Group. 47 p.

24. McArthur, E. D., and B. L. Welch [Compilers]. 1986. 
Proceedings-symposium on the biology of Artemisia and Chrysothamnus. Ogden, UT: USDA Forest Service Intermountain Research Station. General Technical Report INT-200. 398 p. (See especially contributions by Nydegger and Smith, Roberson, Hulet et al., Yoakum, and Clary.)

25. Welch, B. L., AND E. D. McArThur. 1986. Wintering mule deer preference for 21 accessions of big sagebrush. Great Basin Naturalist 46:281-286.

26. Welch, B. L., E. D. MCArthur, And R. L. Rodriguez. 1987. Variation in utilization of big sagebrush accessions by wintering sheep. Journal of Range Management 40:113-115.

27. Wambolt, C. L. 1996. Mule deer and elk foraging preference for 4 sagebrush taxa. Journal of Range Management 49:499-503.

28. SHEEHY, D. P., AND A. H. WINWARD. 1981. Relative palatability of seven Artemisia taxa to mule deer and sheep. Journal of Range Management 34:297-399.

29. Welch, B. L., F. J. Wagstaff, and J. A. Roberson. 1991. Preference of wintering sage grouse for big sagebrush. Journal of Range Management 44:462-465.

30. Hanks, D. L., J. R. Brunner, D. R. Christensen, and A. P. Plummer. 1971. Paper chromatography for determining palatability differences in various strains of big sagebrush. Ogden, UT: USDA Forest Service, Intermountain Forest and
Range Experiment Station. Research Paper INT-101. 9 p. (At the time this paper was published Lahontan low sagebrush was not yet described; it is treated as $A$. tridentata "subgroup Id" in the paper.)

31. Welch, B. L., E. D. McArthur, and J. N. Davis. 1981. Differential preference of wintering mule deer for accessions of big sagebrush and black sagebrush. Journal of Range Management 34:409-411.

32. Smith, A. D., D. M. Beale, And D. D. Doel. 1965. Browse preferences of pronghorn antelope in Southwestern Utah. Thirtieth North American Wildlife Conference. p. 136-141.

33. Clary, W. P. 1986. Black sagebrush response to grazing in the East-central Great Basin. In: E. D. McArthur and B. L. Welch [compilers]. Proceedings-symposium on the biology of Artemisia and Chrysothamnus. Ogden, UT: USDA Forest Service, Intermountain Research Station. General Technical Report INT-200. p. 181-185.

34. McArthur, E. D. 1994. Ecology, distribution, and values of sagebrush within the Intermountain region. In: S. B. Monsen and S. G. Kitchen [compilers]. Proceedings-ecology and management of annual rangelands. Ogden, UT: USDA Forest Service, Intermountain Research Station. General Technical Report INT-GTR-313. p. 347-351.
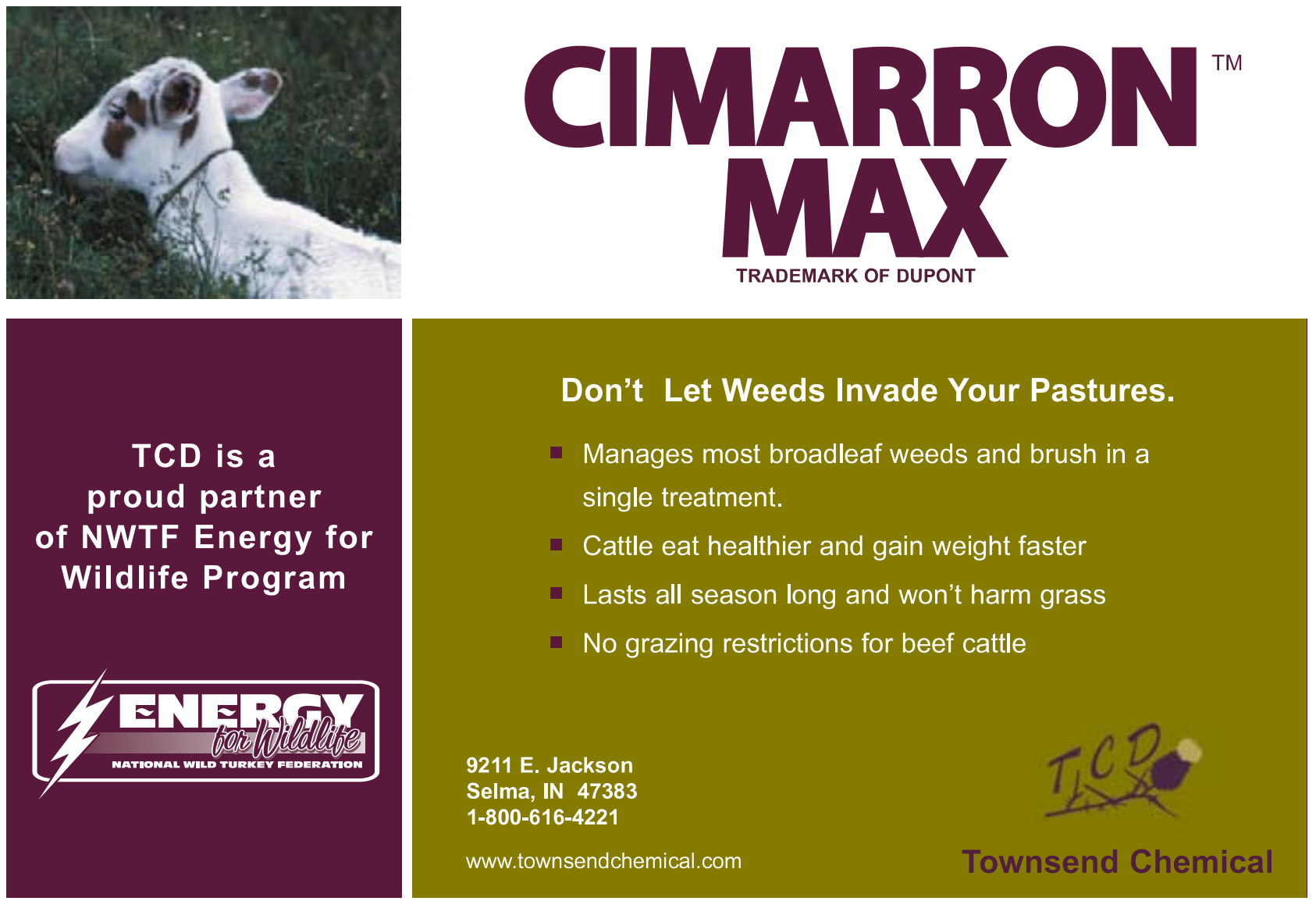